\title{
Pertumbuhan, Hasil dan Efisiensi Pemakaian Air Padi Inpari 33 pada Perlakuan Pupuk Anorganik dan Organik
}

\section{Growth, Yield and Water Use Efficiency of Inpari 33 Rice Genotype to Inorganic and Organic Fertilizer Treatments}

\author{
Zaqiah Mambaul Hikmah ${ }^{1,3}$, Eko Sulistyono $^{2 *}$, dan Zuziana Susanti ${ }^{3}$ \\ ${ }^{1}$ Program Studi Agronomi dan Hortikultura, Sekolah Pascasarjana, Institut Pertanian Bogor \\ ${ }^{2}$ Departemen Agronomi dan Hortikultura, Fakultas Pertanian, Institut Pertanian Bogor \\ (IPB University), Jl. Meranti, Kampus IPB Darmaga, Bogor 16680, Indonesia \\ ${ }^{3}$ Balai Besar Penelitian Tanaman Padi \\ Jl. Raya Sukamandi No 9 Sukamandijaya, Ciasem, Subang 41256 Jawa Barat, Indonesia
}

Diterima 8 November 2021/Disetujui 21 Desember 2021

\begin{abstract}
The priority of agricultural development to supply national food in line with increasing population. One of the ways enhancements of rice productions is application of inorganic fertilizers, but the application inorganic fertilizer in long term causes soil and water degradation. The organic fertilizer would be restoring the soil condition. This research aims to determine growth, yield and water use efficiency in rice Inpari 33 under anorganic and organic fertilizer treatments. The research was conducted from July to December 2020 in IP2TP Sukamandi, Indonesian Centre for Rice Research, Subang-West Java. The research design is split plot with three replications. The main plot was anorganic fertilizers, namely no application fertilizer of NPK, N, K, P, and application NPK fertilizer. Sub-plots were organic fertilizers consisting of manure, straw compost, and non-organic fertilizers. The research results showed that no application $P, K$, and NPK fertilizer increased the number of tillers by 44-49\%, SPAD value 11-12\%, and rice production 33-51\%; and the highest water use efficiency $1.17 \mathrm{~g}$ grain $\mathrm{L}^{-1}$ water was obtained on no application of P. Organic fertilizers were not increase growth, rice production, and water use efficiency. However, there was an interaction between inorganic and organic fertilizer treatments that affected the number of tillers, number of panicles per hill, weight of 1,000 grains and total evapotranspiration.
\end{abstract}

Keywords: compost, evapotranspiration, manure, nutrient, NPK

\section{ABSTRAK}

Prioritas pembangunan pertanian untuk memenuhi kebutuhan pangan nasional semakin meningkat seiring peningkatan jumlah penduduk. Peningkatan produksi salah satunya dengan penggunaan pupuk anorganik, namun penggunaan yang terus menerus memicu terjadinya degradasi lahan dan air. Pupuk organik merupakan salah satu solusi untuk memperbaiki kondisi tersebut. Penelitian bertujuan untuk menganalisis respon pertumbuhan, hasil dan efisiensi pemakaian air padi Inpari 33 pada perlakuan pupuk anorganik dan organik. Penelitian dilaksanakan pada bulan Juli-Desember 2020 di IP2TP Sukamandi Balai Besar Penelitian Tanaman Padi Subang Jawa Barat. Rancangan percobaan yang digunakan split plot design dengan tiga ulangan. Petak utama adalah pupuk anorganik yang terdiri dari perlakuan tanpa NPK (kontrol), tanpa N, tanpa K, tanpa P dan NPK. Anak petak yaitu pupuk organik terdiri dari pupuk kandang sapi, kompos jerami dan tanpa organik. Hasil percobaan menunjukkan bahwa pupuk anorganik meningkatkan jumlah anakan 44-49\%, nilai SPAD 11-12\%, hasil 33-51\%; dan efisiensi pemakaian air tertinggi $1.17 \mathrm{~g}$ gabah $\mathrm{L}^{-1}$ air pada perlakuan tanpa pupuk P. Pupuk organik tidak meningkatkan pertumbuhan, hasil dan efisiensi penggunaan air. Interaksi pupuk anorganik dan organik mempengaruhi jumlah anakan, jumlah malai per rumpun, berat 1,000 butir dan total evapotranspirasi. Penambahan pupuk kandang sapi sangat mempengaruhi jumlah anakan dan total evapotranspirasi pada perlakuan tanpa pupuk $P$.

Kata kunci: evapotranspirasi, hara, kompos, NPK, pupuk kandang

\footnotetext{
*Penulis untuk korespondensi. e-mail: ekosulistyono@apps.ipb.ac.id
} 


\section{PENDAHULUAN}

Peningkatan produksi padi merupakan salah satu prioritas pembangunan pertanian untuk memenuhi kebutuhan pangan nasional yang semakin meningkat seiring dengan peningkatan jumlah penduduk. Jumlah penduduk mencapai 270.20 juta jiwa berdasarkan hasil sensus penduduk September 2020 (BPS, 2021) dengan tingkat konsumsi beras sebesar $111.58 \mathrm{~kg}$ beras per kapita per tahun (Pusat Data dan Informasi Pertanian, 2019). Disisi lain, kenaikan produksi beras sangat kecil, dimana angka sementara produksi beras pada tahun 2021 sebesar 55.27 juta ton GKG.

Manajemen pemupukan merupakan salah satu upaya untuk meningkatkan produksi padi terutama penggunaan pupuk makro sebagai hara essensial yaitu nitrogen $(\mathrm{N})$, pospor (P) dan kalium (K). Kebutuhan tanaman akan $\mathrm{N}$ sangat tinggi salah satunya untuk meningkatkan jumlah anakan, bobot biomass, hasil padi (Triadiati et al., 2012; Hikmah et.al., 2017) dan meningkatkan jumlah malai per rumpun (Xiong et al., 2018). P berperan dalam peningkatan toleransi tehadap cekaman Al (Lestari et.al., 2017) serta meningkatkan efisiensi hasil (Mashtura et al., 2013) dan $\mathrm{K}$ berperan meningkatkan efisiensi penggunaan air pada tanaman (Gebreslassie, 2016).

Penggunaan pupuk anorganik dalam jangka panjang menjadi salah satu penyebab degradasi lahan. Degradasi lahan mempengaruhi $40 \%$ penurunanan air tanah, kualitas perairan dan ekosistem (Pacheco et al., 2018). Selain itu, aplikasi pupuk NPK kimia secara jangka panjang menurunkan kandungan koloni bakteri di dalam tanah 7.32\% sedangkan aplikasi pupuk kandang saja atau kombinasi pupuk kandang dengan NPK kimia secara signifikan mampu meningkatkan keanekaragaman hayati atau koloni bakteri (Cui et al., 2018; Tang et al., 2020). Kombinasi pupuk anorganik dan organik mampu meningkatkan efisiensi pemupukan anorganik (Siswanto et al., 2015) serta mampu meningkatkan keberadaan $\mathrm{C}$ organik tanah (Wang et al., 2012). C organik tertinggi pada kedalaman tanah 0-10 cm (Yang et al., 2020).

Hara, tanah, dan air merupakan tiga komponen yang tidak dapat dipisahkan dari budidaya tanaman. Keseimbangan tiga hal tersebut mendukung produksi tanaman yang dibudidayakan akan berhasil. Pada budidaya padi, air merupakan komponen yang paling besar digunakan sejak awal olah tanah sampai panen dan proses evapotranspirasi merupakan komponen konsumsi air utama pada padi (Arif et al., 2012). Kekeringan pada tanaman padi akan menurunkan hasil panen sebesar 32-48\% (Sulistyono et al., 2011). Hal ini menunjukkan bahwa ketersediaan air merupakan hal utama agar tanaman tetap tumbuh dan berproduksi. Menurut Yang et al. (2020) kombinasi irigasi hemat air dan penambahan biochar jerami bermanfaat untuk perbaikan sifat tanah dan kesuburan sawah. Penambahan bahan organik pada manajemen pemupukan tanaman padi diharapkan mampu meningkatkan kesuburan tanah dan meningkatkan efisiensi penggunaan air tanaman. Penelitian ini dilakukan dengan tujuan untuk mengetahui respon pertumbuhan, hasil dan efisiensi pemakaian air dari padi Inpari 33 pada pupuk anorganik dan organik.

\section{BAHAN DAN METODE}

Percobaan dilaksanakan pada bulan Juli sampai Desember 2020 di IP2TP Balai Besar Penelitian Tanaman Padi Sukamandi Subang Jawa Barat. Pengukuran luas daun, pengeringan sampel dan penghitungan komponen hasil dilakukan di Laboratorium Agronomi, Balai Besar Penelitian Tanaman Padi. Analisa tanah dan pupuk organik dilakukan di Laboratorium Pengujian Balai Penelitian Tanah Bogor. Bahan yang digunakan yaitu benih padi varietas Inpari 33, pupuk kandang (pukan) sapi ( 2 ton ha $\left.{ }^{-1}\right)$, jerami padi ( 5 ton ha $^{-1}$ ), pupuk Urea, SP36 dan $\mathrm{KCl}$. Peralatan yang digunakan meliputi meteran, lisimeter sederhana, penangkar hujan, panci kelas A, timbangan analitik, leaf area meter Li3100, SPAD meter, bor tanah, oven dan alat analisis tanah serta pupuk organik.

Percobaan ini menggunakan rancangan petak terbagi (split-plot design). Petak utama yaitu pemupukan anorganik yang terdiri dari perlakuan tanpa NPK (kontrol), tanpa N, tanpa K, tanpa P, dan menggunakan NPK lengkap yang berasal dari pupuk tunggal. Pupuk NPK yang dimaksud berupa $311 \mathrm{~kg}$ Urea ha-1 $^{-1}\left(10 \mathrm{~N} \mathrm{~kg} \mathrm{ha}^{-1}\right)$, SP36 $95.5 \mathrm{~kg} \mathrm{ha}^{-1}$ (15 $\left.\mathrm{P} \mathrm{kg} \mathrm{ha}^{-1}\right)$ dan KCL $100 \mathrm{~kg} \mathrm{ha}^{-1}\left(50 \mathrm{~K} \mathrm{~kg} \mathrm{ha}^{-1}\right)$. Anak petak yaitu aplikasi pupuk organik terdiri dari pupuk kandang 2 ton $\mathrm{ha}^{-1}$, jerami 5 ton ha $\mathrm{h}^{-1}$ dan tanpa pupuk organik. Satuan petak percobaan berukuran $6.5 \mathrm{~m} \times 7 \mathrm{~m}$. Bibit dipindah tanam 18 hari setelah semai (HSS) dengan jumlah bibit 3 bibit per lubang tanam dan jarak tanam $25 \times 25 \mathrm{~cm}$. Pupuk organik diberikan 1 minggu sebelum tanam. Pupuk anorganik Urea diaplikasikan 3 kali yaitu 7 hari setelah tanam (HST), 30 HST, dan fase primordia, pupuk SP-36 diaplikasikan pada 7 HST serta pupuk $\mathrm{KCl}$ diaplikasikan pada 7 HST dan fase primordia.

Peubah pengamatan pertumbuhan meliputi jumlah anakan, luas daun, dan kandungan klorofil daun (SPAD). Kandungan klorofil daun diukur menggunakan chlorophyll meter SPAD-502Plus. Pengamatan dilakukan terhadap 12 rumpun tanaman contoh setiap plot percobaan yang dipilih secara acak. Pengamatan dilakukan pada umur 21 HST, 35 HST, dan berbunga. Peubah komponen hasil dan hasil meliputi anakan produktif, jumlah gabah per malai, bobot 1,000 butir gabah, dan gabah kering panen (GKP). Panen dilakukan dengan teknik ubinan luas $2.5 \mathrm{~m}$ × $3 \mathrm{~m}$ dan hasil panen ditimbang serta diukur kadar airnya.

Pengamatan air dilakukan setiap dua hari sekali untuk mengukur evapotranspirasi. Pengukuran menggunakan metoda yang dikembangkan oleh Sosrodarsono dan Takeda (1983). Pengukuran menggunakan lisimeter yang terdiri dari 2 drum yaitu drum A dasar terbuka dan drum B tertutup. Masing-masing drum ditanami padi di dalamnya dengan jarak tanam $25 \mathrm{~cm}$ x $25 \mathrm{~cm}$. Tinggi air awal masing-masing drum adalah $2.6 \mathrm{~cm}$ atau $26 \mathrm{~mm}$ sebagai $\mathrm{H}_{0}$ dan merupakan 
tinggi genangan air pada semua satuan percobaan (Gambar 1). Pengamatan tinggi genangan dalam drum dilakukan setiap dua hari sekali dan dicatat sebagai $\mathrm{H}_{1} \mathrm{~mm}$. Setelah selesai pengamatan, tinggi genangan dalam drum dikembalikan menjadi $26 \mathrm{~mm}$ kembali. Penghitungan neraca air pada drum A menggunakan rumus: $\mathrm{P}=\mathrm{ET}+\mathrm{Pk}+\left(\mathrm{H}_{1}-\mathrm{H}_{0}\right)$ sedangkan penghitungan neraca air pada drum $\mathrm{B}$ menggunakan rumus: $\mathrm{P}=\mathrm{ET}+\left(\mathrm{H}_{1}-\mathrm{H}_{0}\right)$, dimana: $\mathrm{P}=$ presipitasi, $\mathrm{H} 1=$ tinggi air saat pengamatan $(\mathrm{mm}), \mathrm{ET}=$ evapotranspirasi, $\mathrm{H} 0=$ tinggi air awal $(26 \mathrm{~mm}), \mathrm{Pk}=$ perkolasi.

Analisa tanah dilakukan sebelum tanam. Analisis Corganik tanah dengan metode Walkley dan Black, N-total menggunakan metode Kjeldhal, P-total dan K-total dengan Ekstrak $\mathrm{HCl} 25 \%$. Kapasitas tukar kation (KTK) ditetapkan dengan menggunakan $\mathrm{NH}_{4}$-Acetat $1 \mathrm{~N}$ pH 7.0. Analisa standar mutu pupuk organik yang digunakan mengacu pada persyaratan teknis minimal pupuk organik Kepmentan tahun 2019. Analisis C-Organik menggunakan metode pengabuan, bahan ikutan disaring dengan Sieve Mash, kadar air dengan oven, $\mathrm{pH}$ dengan $\mathrm{pH}$ meter, hara makro $\mathrm{N}$ dengan metode Kjeldhal, $\mathrm{P}_{2} \mathrm{O}_{5}$ dengan $\mathrm{HNO}_{3}$ Spektrofotometri, analisa $\mathrm{K}_{2} \mathrm{O}$ dengan $\mathrm{HNO}_{3} / \mathrm{F}$-AAS. Analisis data menggunakan sidik ragam, apabila dalam sidik ragam 5\% terdapat pengaruh nyata maka dilanjutkan dengan uji DMRT (Duncan's MuLiple Range Test).

\section{HASIL DAN PEMBAHASAN}

\section{Karakteristik Tanah Lokasi Percobaan}

Lahan percobaan mempunyai tekstur tanah pasir liat lempung berdebu dan bersifat masam. Lahan merupakan sawah irigasi masam yang sudah terdegradasi. Hal ini yang menjadi salah satu penyebab pertumbuhan tanaman kurang maksimum. Adapun ciri tanah terdegradasi menurut Balittanah (2009) yaitu kandungan C-organik tanah sangat rendah $(<1 \%)$, kandungan $\mathrm{N}$ total rendah $(0.1-0.2 \%)$, kandungan $\mathrm{P}$-potensial beragam yaitu $\mathrm{P}$ potensial rendah pada tanah tanpa pupuk $P$ hingga sangat tinggi pada tanah yang di pupuk NPK. Status K potensial sangat rendah hingga

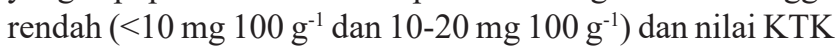
tanah rendah (5-16 $\left.\mathrm{cmol} \mathrm{kg}^{-1}\right)$ (Tabel 1). Lokasi percobaan berdasarkan Peraturan Menteri Pertanian tahun 2013 mengenai kelas kesesuaian lahan yang dapat diusahakan untuk komoditas tanaman padi sawah irigasi maka plot percobaan masuk pada kelas $\mathrm{S} 2$. Kelas ini memiliki ciri KTK tanah 5-16 $\mathrm{cmol} \mathrm{kg}^{-1}, \mathrm{pH} 4.5-5.5$, C-organik 0.8-1.2\%, hara tersedia terdiri dari $\mathrm{N}$ total yang rendah, $\mathrm{P}_{2} \mathrm{O}_{5}$ sedang ke tinggi dan $\mathrm{K}_{2} \mathrm{O}$ rendah dan sangat rendah. Kelas lahan S2 merupakan lahan yang mempunyai faktor pembatas dan mempengaruhi produktivitas lahan sehingga untuk meningkatkan produktivitasnya diperlukan tambahan input. Manajemen pemupukan dan pengairan merupakan salah satu input yang dapat dilakukan untuk meningkatkan produksi padi. Manajemen pemupukan yang tepat merupakan salah satu usaha untuk meningkatkan produktivitas lahan sehingga diharapkan produksi dapat meningkat.

\section{Komposisi dan Kandungan Hara Pupuk Organik Pupuk Kandang dan Kompos Jerami}

Pupuk organik yang digunakan pada percobaan mengacu pada Keputusan Menteri Pertanian RI 261/KPTS/ SR.310/M/42/2019 mengenai persyaratan teknis minimal pupuk organik, pupuk hayati dan pembenah tanah. Adapun persyaratan meliputi komposisi dan kandungan hara yang harus dipenuhi oleh pupuk organik. Pada parameter COrganik, $\mathrm{C} / \mathrm{N}$ rasio, $\mathrm{pH} \mathrm{H}_{2} \mathrm{O}$, adanya kandungan E. Coli serta Salmonella pada pupuk organik serta kandungan logam berat $\mathrm{Pb}$ memenuhi persyaratan standar mutu, namun kadar air pada kompos jerami melebihi standar mutu yang dipersyaratkan yaitu maksimal 20\% (Tabel 2). Kandungan hara $\mathrm{N}$ yang memenuhi persyaratan minimum adalah kompos jerami dan hal ini sesuai dengan hasil penelitian Jing et al. (2020) bahwa kompos jerami mempunyai kandungan level $\mathrm{N}$ yang lebih tinggi dibandingkan dengan jerami jagung dan gandum. Secara umum, pupuk organik yang digunakan baik pukan maupun kompos jerami memenuhi syarat minimum standar mutu pupuk organik yang ditetapkan oleh Kementerian Pertanian.

\section{Pertumbuhan dan Hasil Padi pada Perlakuan Pupuk Anorganik dan Organik}

Jumlah Anakan. Pupuk anorganik NPK memberikan pengaruh yang nyata terhadap jumlah anakan pada fase vegetatif dan pengaruh yang sangat nyata pada fase generatif. Jumlah anakan bertambah seiring dengan bertambahnya umur tanaman lalu menurun setelah fase anakan maksimum. Pada fase anakan maksimum, jumlah

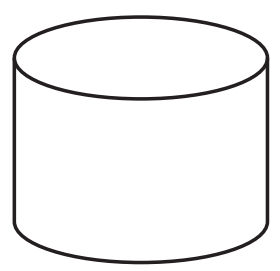

A

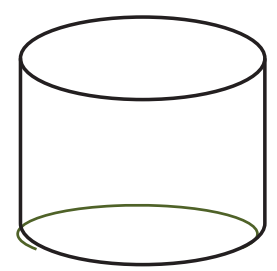

B

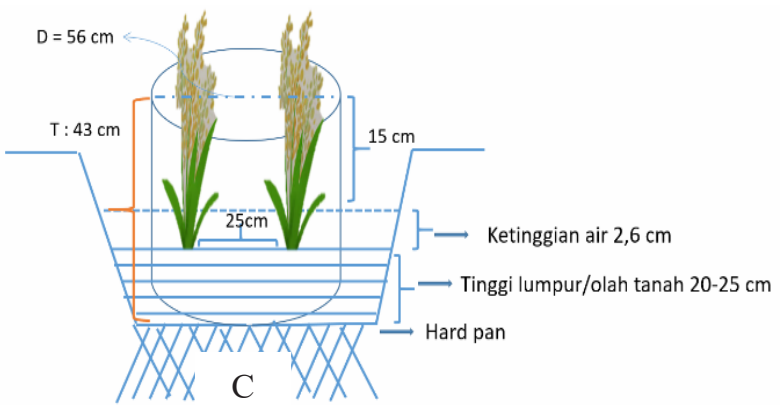

Gambar 1. Lisimeter sederhana menggunakan drum, drum A dasar drum terbuka, drum B dasar tertutup dan C letak drum per satuan percobaan 
Tabel 1. Karakteristik tanah di lokasi penelitian sebelum perlakuan

\begin{tabular}{|c|c|c|c|c|c|c|c|c|}
\hline \multirow{2}{*}{\multicolumn{2}{|c|}{ Perlakuan pupuk }} & \multirow{3}{*}{$\frac{\mathrm{pH}}{\frac{\mathrm{H}_{2} \mathrm{O}}{5.5}}$} & \multicolumn{3}{|c|}{ Bahan organik } & $\mathrm{P}_{2} \mathrm{O}_{5}$ pot & $\mathrm{K}_{2} \mathrm{O}$ pot & \multirow{3}{*}{$\begin{array}{c}\text { KTK } \\
\left(\mathrm{cmol} \mathrm{kg}^{-1}\right) \\
13.99\end{array}$} \\
\hline & & & \multirow{2}{*}{$\frac{\mathrm{C}-\mathrm{Org}(\%)}{0.83 \mathrm{sr}}$} & \multirow{2}{*}{$\frac{\mathrm{N}-\text { total }(\%)}{0.11 \mathrm{r}}$} & \multirow{2}{*}{$\begin{array}{r}\mathrm{C} / \mathrm{N} \\
8 \mathrm{r}\end{array}$} & \multicolumn{2}{|c|}{$\mathrm{mg} 100 \mathrm{~g}^{-1}$} & \\
\hline Kontrol & Pukan & & & & & $22 \mathrm{~s}$ & $8 \mathrm{sr}$ & \\
\hline Kontrol & Kompos & 5.3 & $0.99 \mathrm{sr}$ & $0.12 \mathrm{r}$ & $8 \mathrm{r}$ & $28 \mathrm{~s}$ & $10 \mathrm{r}$ & 12.32 \\
\hline Kontrol & Tanpa organik & 5.3 & $0.87 \mathrm{sr}$ & $0.10 \mathrm{r}$ & $9 r$ & $20 \mathrm{r}$ & $7 \mathrm{sr}$ & 13.78 \\
\hline Tanpa N & Pukan & 5.1 & $1.07 \mathrm{r}$ & $0.12 \mathrm{r}$ & $9 \mathrm{r}$ & $66 t$ & $12 \mathrm{r}$ & 12.28 \\
\hline Tanpa N & Kompos & 5.1 & $0.06 \mathrm{sr}$ & $0.12 \mathrm{r}$ & $1 \mathrm{sr}$ & $74 \mathrm{st}$ & $13 r$ & 11.05 \\
\hline Tanpa N & Tanpa organik & 4.9 & $0.99 \mathrm{sr}$ & $0.11 \mathrm{r}$ & $9 r$ & $54 \mathrm{t}$ & $11 \mathrm{r}$ & 10.97 \\
\hline Tanpa K & Pukan & 5.6 & $1.02 \mathrm{r}$ & $0.09 \mathrm{sr}$ & $11 \mathrm{~s}$ & $41 \mathrm{t}$ & $6 \mathrm{sr}$ & 12.29 \\
\hline Tanpa K & Kompos & 5.5 & $1.02 \mathrm{r}$ & $0.12 \mathrm{r}$ & $9 \mathrm{r}$ & $39 \mathrm{~s}$ & $5 \mathrm{sr}$ & 10.23 \\
\hline Tanpa K & Tanpa organik & 5.7 & $0.91 \mathrm{sr}$ & $0.09 \mathrm{sr}$ & $10 \mathrm{r}$ & $33 \mathrm{~s}$ & $5 \mathrm{sr}$ & 13.28 \\
\hline Tanpa P & Pukan & 5.4 & $1.02 \mathrm{r}$ & $0.10 \mathrm{r}$ & $10 \mathrm{r}$ & $24 \mathrm{~s}$ & $7 \mathrm{sr}$ & 11.69 \\
\hline Tanpa P & Kompos & 5.2 & $0.95 \mathrm{sr}$ & $0.10 \mathrm{r}$ & $10 \mathrm{r}$ & $20 \mathrm{r}$ & $9 \mathrm{sr}$ & 8.21 \\
\hline Tanpa P & Tanpa organik & 5.2 & $0.93 \mathrm{sr}$ & $0.10 \mathrm{r}$ & $9 r$ & $20 \mathrm{r}$ & $8 s r$ & 11.71 \\
\hline + NPK & Pukan & 4.7 & $1.25 \mathrm{r}$ & $0.12 \mathrm{r}$ & $10 \mathrm{r}$ & $47 \mathrm{t}$ & $9 \mathrm{sr}$ & 11.26 \\
\hline + NPK & Kompos & 4.9 & $1.06 \mathrm{r}$ & $0.12 \mathrm{r}$ & $9 r$ & $43 \mathrm{t}$ & $8 \mathrm{sr}$ & 14.75 \\
\hline + NPK & Tanpa organik & 4.7 & $1.14 \mathrm{r}$ & $0.12 \mathrm{r}$ & $10 \mathrm{r}$ & $44 t$ & $6 \mathrm{sr}$ & 10.97 \\
\hline Rata-rata & & 5.2 & 0.94 & 0.11 & 8.8 & 38.33 & 8.27 & 11.92 \\
\hline
\end{tabular}

Keterangan: $\mathrm{sr}=$ sangat rendah; $\mathrm{r}=$ rendah; $\mathrm{s}=$ sedang; $\mathrm{t}=$ tinggi; $\mathrm{st}=$ sangat tinggi (Balittanah, 2009)

anakan perlakuan tanpa $\mathrm{P}$, tanpa $\mathrm{K}$ dan NPK meningkat 44-49\% dibandingkan tanpa pupuk NPK dan tanpa pupuk N (Tabel 3). Hal ini menunjukkan bahwa tanaman memerlukan pupuk $\mathrm{N}$ untuk pertambahan jumlah anakan dan peningkatan jumlah anakan sesuai dengan peningkatan dosis pupuk N (Hikmah et al., 2017; Siska dan Lenin 2020). Nitrogen merupakan salah satu unsur hara esensial yang berperan penting dalam menjalankan proses metabolisme untuk pertumbuhan dan perkembangan tanaman yang cepat, berkualitas dan komponen utama asam amino sebagai penyusun protein. Puluhan asam amino membentuk protein salah satunya untuk pertumbuhan tanaman yang tercermin dalam peningkatan jumlah anakan, tinggi tanaman, bobot kering, dan panjang malai (Leghari et al., 2016). Tanpa nitrogen, tanaman tidak dapat menghasilkan asam amino yang selanjutnya akan terganggunya proses metabolisme

Tabel 2. Komposisi dan kandungan hara pupuk organik yang digunakan pada penelitian

\begin{tabular}{|c|c|c|c|c|}
\hline Parameter & Satuan & $\begin{array}{c}\text { Standar mutu } \\
\text { pupuk organik } \\
\text { (Kepmentan. 2019) }\end{array}$ & $\begin{array}{c}\text { Kotoran sapi } \\
\text { (Pukan) }\end{array}$ & Kompos jerami \\
\hline Kadar C-organik & $\%$ (adbk) & Minimum 15 & 23.32 & 28.29 \\
\hline $\mathrm{C} / \mathrm{N}$ rasio & & $<25$ & 21.00 & 13.00 \\
\hline Kadar air & $\%(\mathrm{w} / \mathrm{w})$ & $8-20$ & 15.80 & 58.70 \\
\hline $\mathrm{pH} \mathrm{H} \mathrm{H}_{2} \mathrm{O}$ & $\%($ adbk $)$ & $4-9$ & 7.90 & 8.80 \\
\hline E. Coli & $\mathrm{MPN} / \mathrm{g}$ & $<102$ & $<30$ & $<30$ \\
\hline Salmonella sp. & $\mathrm{MPN} / \mathrm{g}$ & $<102$ & $<30$ & $<30$ \\
\hline \multicolumn{5}{|l|}{ Kand. hara makro } \\
\hline $\mathrm{N}$ & & & 1.11 & 2.13 \\
\hline $\mathrm{P}_{2} \mathrm{O}_{5}$ & $\%(\mathrm{adbk})$ & Minimum 2 & 1.97 & 0.66 \\
\hline $\mathrm{K}_{2} \mathrm{O}$ & & & 2.50 & 1.82 \\
\hline \multicolumn{5}{|l|}{ Logam berat } \\
\hline $\mathrm{Pb}$ & ppm & Maksimum 50 & 9.02 & 6.61 \\
\hline
\end{tabular}

Keterangan: Hasil analisa laboratorium tanah. Balai Besar Penelitian Tanah Bogor 2020 
tanaman jika mengalami kekurangan pasokan nitrogen. Hal ini karena regulasi jumlah anakan padi terkait dengan transport auxin polar yang diatur oleh nitrogen (Hou et al., 2021).

Aplikasi pupuk organik yang bersumber dari pupuk kandang (pukan) sapi dan kompos jerami memberikan pengaruh yang sangat nyata pada jumlah anakan padi umur 35 HST dan terjadi interaksi antara pupuk anorganik dan organik terhadap jumlah anakan (Tabel 3). Hal ini berarti bahwa respon jumlah anakan terhadap pupuk anorganik tergantung dari pupuk organik. Pada perlakuan tanpa P, terlihat respon yang sangat signifikan pada penambahan pupuk organik. Jumlah anakan pada perlakuan pupuk organik baik itu pukan maupun kompos jerami meningkat sebesar 6.2\% dibandingkan tanpa organik (Gambar 2). Hal ini sesuai dengan hasil penelitian Suyono dan Citraresmini (2010) bahwa ketersediaan P di dalam tanah meningkat seiring dengan peningkatan penambahan pupuk kandang sapi. Horta et al. (2018) menambahkan bahwa pemberian pupuk organik meningkatkan efisiensi penggunaan pupuk $\mathrm{P}$ oleh tanaman Ryegrass dibandingkan dengan tanaman yang ditambahkan pupuk $\mathrm{P}$ anorganik. Pupuk organik berupa kompos dan kotoran sapi menunjukkan performa agronomi terbaik, efisiensi $\mathrm{P}$ dan mengurangi kehilangan P oleh limpasan atau erosi. Berbeda pada perlakuan pupuk NPK, pupuk organik tidak mempengaruhi jumlah anakan pada tanaman padi. Hal ini bisa terjadi karena kebutuhan tanaman akan hara telah tercukupi oleh pupuk NPK yang diberikan.

Kandungan Klorofil Daun. Jumlah relatif kandungan klorofil pada daun dipresentasikan melalui nilai pada Soil Plant Analysis Development (SPAD). SPAD digunakan untuk memprediksi status nitrogen berdasarkan luas daun dan tingkat warna daun tanaman secara sederhana, cepat dan praktis tanpa merusak bagian tanaman (Esfahani et al., 2008) dan pengukuran dilakukan pada posisi $1 / 3$ dan $2 / 3$ bagian daun padi untuk memperhitungkan distribusi dinamis klofil di sepanjang daun (Yuan et al., 2016). Hasil penelitian menunjukkan bahwa pemupukan NPK memberikan respon yang sangat nyata terhadap nilai SPAD pada umur 35 HST dan fase berbunga. Perlakuan tanpa P, tanpa K dan NPK dapat meningkatkan nilai SPAD $11-12 \%$ dibandingkan perlakuan tanpa NPK dan tanpa pupuk N (Tabel 3). Nilai SPAD perlakuan tanpa $\mathrm{K}$ dan tanpa $\mathrm{P}$ tidak berbeda nyata dengan NPK karena pada perlakuan tersebut hara N masih diberikan. Menurut Hidayah et al. (2019) pada tanaman padi, besar kecilnya nilai SPAD dipengaruhi oleh kecukupan nutrisi terutama kecukupan hara N. Kekurangan nitrogen menyebabkan munculnya klorosis (perubahan warna daun dari hijau menjadi kuning), bintik ungu dan merah, serta membatasi pertumbuhan tunas lateral. Yuan et al. (2016) juga menjelaskan bahwa kelebihan nitrogen juga merugikan tanaman, karena menyebabkan pertumbuhan vegetatif yang berlebih.

Luas Daun. Pemupukan anorganik memberikan pengaruh yang sangat nyata terhadap luas daun. Pada fase berbunga, perlakuan tanpa $\mathrm{P}$, tanpa $\mathrm{K}$ dan NPK dapat meningkatkan luas daun 175-195\% dibandingkan perlakuan tanpa NPK dan tanpa N. Hal ini menurut Leghari et al. (2016) bahwa luas daun maksimum dan bobot daun total tanaman sangat dipengaruhi oleh ketersediaan nitrogen untuk meningkatkan proses fotosintesis. Widianti et al. (2017) menyatakan bahwa luas daun menentukan sebagian besar proses fotosintesis dan laju fotosintesis. Xiao et al. (2019) menambahkan bahwa karbon fotosintesis yang dilepaskan di rizosfer memainkan peran penting dalam penyerapan $C$, aktivitas mikroba dan ketersediaan nutrisi tanah. Pupuk N dapat memodifikasi alokasi dan dinamika fotosintesis padi sawah dan meningkatkan $\mathrm{C}$ tanah terutama pada biomassa akar yang lebih besar.

Komponen hasil dan hasil. Perlakuan pupuk anorganik nyata mempengaruhi jumlah anakan produktif, jumlah gabah per malai, bobot 1000 butir, persentase gabah isi dan hasil padi. Perlakuan tanpa P, tanpa K dan NPK secara nyata dapat menaikkan hasil gabah sebesar 23-51\% dibandingkan tanpa NPK dan tanpa N (Tabel 4). Penambahan pupuk organik tidak memberikan pengaruh secara nyata pada peubah komponen hasil dan hasil. Menurut Li et al. (2019) penggunaan organik dalam jumlah besar berfungsi untuk meningkatkan $\mathrm{C}$ organik tanah dan suplai nutrisi namun belum ada korelasi yang signifikan antara aplikasi organik dengan peningkatan gabah. Hal ini diperjelas dengan hasil penelitian Yin et al. (2020) bahwa aplikasi organik berupa biochar tidak berpengaruh nyata terhadap komponen hasil dan hasil gabah. Legowo et al. (2020) menambahkan bahwa pupuk organik meningkatkan kesuburan tanah dan produktivitas air masing-masing $15 \%$ dan $19 \%$ dibandingkan cara budidaya konvensional dimana sumber nutrisi dari pupuk anorganik. Soebandiono et al. (2021) menyatakan bahwa aplikasi pupuk organik dalam jangka

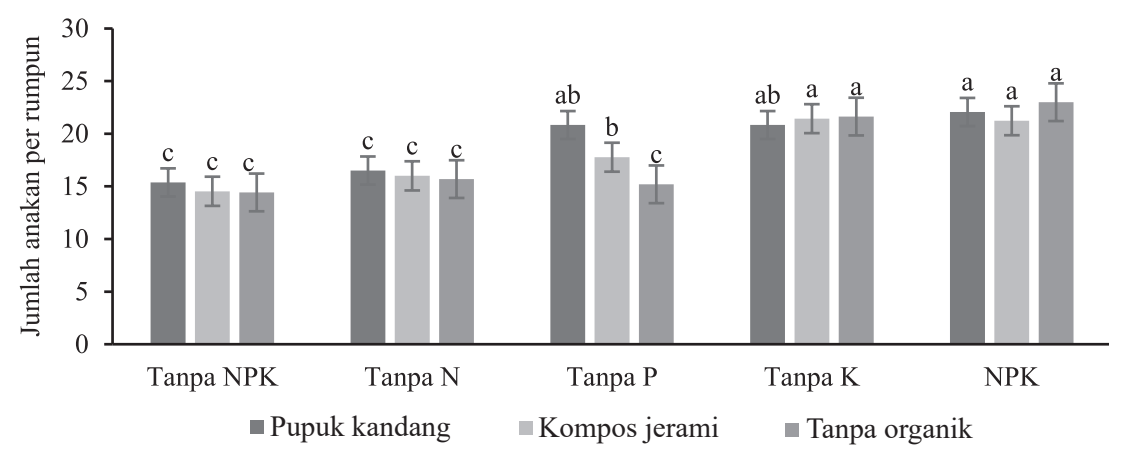

Gambar 2. Interaksi pupuk anorganik dan organik terhadap jumlah anakan padi pada umur 35 HST 
Tabel 3. Jumlah anakan, SPAD, luas daun pada perlakuan pupuk anorganik dan organik

\begin{tabular}{|c|c|c|c|c|c|c|c|c|c|}
\hline \multirow{3}{*}{$\begin{array}{l}\text { Perlakuan/umur } \\
\text { tanaman }\end{array}$} & \multicolumn{9}{|c|}{ Pengamatan } \\
\hline & \multicolumn{3}{|c|}{ Jumlah anakan } & \multicolumn{3}{|c|}{ SPAD } & \multicolumn{3}{|c|}{ Luas daun } \\
\hline & $21 \mathrm{HST}$ & $35 \mathrm{HST}$ & Berbunga & $21 \mathrm{HST}$ & 35 HST & Berbunga & $21 \mathrm{HST}$ & $35 \mathrm{HST}$ & Berbunga \\
\hline \multicolumn{10}{|l|}{ Pupuk anorganik } \\
\hline Tanpa NPK & $9.2 \mathrm{~b}$ & $14.8 \mathrm{~b}$ & $13.1 \mathrm{~b}$ & $35.16 \mathrm{a}$ & $35.48 b c$ & $36.22 b$ & $206.67 \mathrm{c}$ & $535.80 \mathrm{~b}$ & $1,049.00 \mathrm{c}$ \\
\hline Tanpa N & $10.9 \mathrm{ab}$ & $16.1 \mathrm{~b}$ & $14.2 \mathrm{~b}$ & $35.51 \mathrm{a}$ & $33.50 \mathrm{c}$ & $36.94 b$ & $272.00 \mathrm{bc}$ & $658.30 \mathrm{~b}$ & $980.50 \mathrm{c}$ \\
\hline Tanpa K & $11.9 \mathrm{a}$ & $21.3 \mathrm{a}$ & $19.2 \mathrm{a}$ & $38.14 \mathrm{a}$ & $40.32 \mathrm{a}$ & $40.90 \mathrm{a}$ & $314.35 \mathrm{ab}$ & $1,159.20 \mathrm{a}$ & $2,673.70 \mathrm{ab}$ \\
\hline Tanpa P & $9.2 b$ & $17.9 \mathrm{~b}$ & $18.5 \mathrm{a}$ & $36.19 \mathrm{a}$ & $37.77 \mathrm{ab}$ & $39.68 \mathrm{a}$ & $210.67 \mathrm{c}$ & $675.90 b$ & $2,192.50 \mathrm{~b}$ \\
\hline NPK & $12.4 \mathrm{a}$ & $22.1 \mathrm{a}$ & $19.2 \mathrm{a}$ & $37.60 \mathrm{a}$ & $37.18 b$ & $40.28 \mathrm{a}$ & $386.13 \mathrm{a}$ & $1,224.80 \mathrm{a}$ & $2,890.80 \mathrm{a}$ \\
\hline \multicolumn{10}{|l|}{ Pupuk organik } \\
\hline Pupuk kandang & $11.0 \mathrm{a}$ & $19.1 \mathrm{a}$ & $17.0 \mathrm{a}$ & $36.77 \mathrm{a}$ & $36.73 a$ & $38.74 a$ & $291.68 \mathrm{a}$ & $963.06 \mathrm{a}$ & $2,265.90 \mathrm{a}$ \\
\hline Kompos jerami & $10.7 \mathrm{a}$ & $18.2 \mathrm{ab}$ & $16.9 \mathrm{a}$ & $36.23 \mathrm{a}$ & $36.95 a$ & $38.64 \mathrm{a}$ & $282.70 \mathrm{a}$ & $842.24 \mathrm{ab}$ & $1,803.30 \mathrm{~b}$ \\
\hline Tanpa organik & $10.4 \mathrm{a}$ & $18.0 \mathrm{~b}$ & $16.8 \mathrm{a}$ & $36.55 \mathrm{a}$ & $36.86 \mathrm{a}$ & $39.03 \mathrm{a}$ & $259.52 \mathrm{a}$ & $747.10 \mathrm{~b}$ & $1,802.60 \mathrm{~b}$ \\
\hline Interaksi & tn & $* *$ & tn & tn & tn & tn & th & tn & tn \\
\hline
\end{tabular}

Keterangan: Angka yang diikuti huruf yang sama pada kolom yang sama tidak berbeda nyata berdasarkan DMRT taraf $\alpha=5 \%$. Tanda ** menunjukkan interaksi antara pupuk anorganik dan organik. tn menunjukkan interaksi yang tidak nyata antara pupuk anorganik dan organik

panjang memiliki manfaat untuk perbaikan lingkungan dan agronomi, namun dalam jangka pendek belum mampu meningkatkan hasil gabah. Selain itu pemanfaatan organik mengurangi ketergantungan pupuk anorganik.

\section{Efisiensi Penggunaan Air pada Perlakuan Pupuk Anorganik dan Organik}

Produksi padi memiliki kaitan erat dengan proses evapotranspirasi. Evapotranspirasi tertinggi pada perlakuan tanpa K dan NPK, sedang evapotranspirasi terendah pada perlakuan tanpa P sebesar $448930 \mathrm{~L} \mathrm{ha}^{-1}$ namun mempunyai nilai efisiensi pemakaian air tertinggi yaitu $1.17 \mathrm{~g}$ gabah $\mathrm{L}^{-1}$ air (Tabel 5). Hal ini berarti bahwa tanaman padi memerlukan 1 L air untuk memproduksi $1.17 \mathrm{~g}$ gabah. Menurut Herdiyanti et.al (2021) tanaman memiliki efisiensi penggunaan air tertinggi jika kebutuhan air tanaman sedikit namun hasil gabah kering giling tetap tinggi. Efisiensi evapotranspirasi yang tinggi ini didukung oleh karakter tanaman selama masa pertumbuhan. Pada perlakuan tanpa P, tanaman beradaptasi dengan mempersempit luasan permukaan daun dan memperkecil ukuran tanaman. Daun

Tabel 4. Pengaruh pupuk anorganik dan organik terhadap komponen hasil dan hasil

\begin{tabular}{|c|c|c|c|c|c|}
\hline \multirow[b]{2}{*}{$\begin{array}{l}\text { Perlakuan/umur } \\
\text { tanaman }\end{array}$} & \multicolumn{5}{|c|}{ Komponen hasil dan hasil } \\
\hline & $\begin{array}{c}\text { Jumlah anakan } \\
\text { produktif }\end{array}$ & $\begin{array}{l}\text { Jumlah gabah } \\
\text { per malai }\end{array}$ & $\begin{array}{c}\text { Bobot } 1,000 \text { butir } \\
(\mathrm{g})\end{array}$ & $\begin{array}{c}\text { Gabah isi } \\
(\%)\end{array}$ & $\begin{array}{c}\text { Hasil gabah } \\
\text { (ton } \text { ha }^{-1} \mathrm{GKG} \text { ) }\end{array}$ \\
\hline \multicolumn{6}{|l|}{ Pupuk anorganik } \\
\hline Tanpa NPK & $12.5 \mathrm{c}$ & $74.6 b$ & $27.96 \mathrm{~b}$ & $88.83 a$ & $3.48 b$ \\
\hline Tanpa N & $10.6 \mathrm{~d}$ & $84.1 \mathrm{a}$ & $28.07 b$ & $80.77 b$ & $3.80 \mathrm{~b}$ \\
\hline Tanpa K & $15.7 b$ & $86.5 \mathrm{a}$ & $29.11 \mathrm{a}$ & $83.46 \mathrm{ab}$ & $4.64 \mathrm{a}$ \\
\hline Tanpa P & $18.1 \mathrm{a}$ & $85.4 \mathrm{a}$ & $28.94 \mathrm{a}$ & $83.91 \mathrm{ab}$ & $5.27 \mathrm{a}$ \\
\hline NPK & $16.0 \mathrm{~b}$ & $87.0 \mathrm{a}$ & $29.33 \mathrm{a}$ & $81.49 b$ & $4.70 \mathrm{a}$ \\
\hline \multicolumn{6}{|l|}{ Pupuk organik } \\
\hline Pupuk kandang & $14.2 \mathrm{a}$ & $85.7 \mathrm{a}$ & $28.75 \mathrm{a}$ & $83.70 \mathrm{a}$ & $4.42 \mathrm{a}$ \\
\hline Kompos jerami & $14.9 \mathrm{a}$ & $83.9 \mathrm{a}$ & $28.74 \mathrm{a}$ & $84.62 \mathrm{a}$ & $4.48 \mathrm{a}$ \\
\hline Tanpa organik & $14.6 \mathrm{a}$ & $81.0 \mathrm{a}$ & $28.55 \mathrm{a}$ & $82.75 a$ & $4.23 \mathrm{a}$ \\
\hline Interaksi & $* *$ & tn & $* *$ & tn & $\operatorname{tn}$ \\
\hline
\end{tabular}

Keterangan: Angka yang diikuti huruf yang sama pada kolom yang sama tidak berbeda nyata berdasarkan DMRT taraf $\alpha=5 \%$. ** menunjukkan interaksi antara pupuk anorganik dan organik, tn menunjukkan interaksi yang tidak nyata antara pupuk anorganik dan organik 
Tabel 5. Total evapotranspirasi dan efisiensi pemakaian air pada perlakuan pupuk anorganik dan organik

\begin{tabular}{|c|c|c|c|}
\hline Perlakuan & $\begin{array}{l}\text { Total evapotranspirasi } \\
(\mathrm{mm})\end{array}$ & $\begin{array}{l}\text { Total evapotranspirasi } \\
\left(\mathrm{L} \mathrm{ha}^{-1}\right)\end{array}$ & $\begin{array}{l}\text { Efisiensi pemakaian air } \\
\left(\mathrm{g} \mathrm{L}^{-1}\right)\end{array}$ \\
\hline \multicolumn{4}{|l|}{ Pupuk anorganik } \\
\hline Tanpa NPK & $453.68 \mathrm{a}$ & $453680 \mathrm{a}$ & $0.77 \mathrm{c}$ \\
\hline Tanpa N & $438.56 \mathrm{a}$ & $438560 \mathrm{a}$ & $0.87 b c$ \\
\hline Tanpa K & $505.64 a$ & $505640 \mathrm{a}$ & $0.92 b$ \\
\hline Tanpa P & $452.59 \mathrm{a}$ & $452590 \mathrm{a}$ & $1.17 \mathrm{a}$ \\
\hline NPK & $501.19 \mathrm{a}$ & $501190 \mathrm{a}$ & $0.94 b$ \\
\hline \multicolumn{4}{|l|}{ Pupuk organik } \\
\hline Pupuk kandang & $462.78 \mathrm{a}$ & $462780 \mathrm{a}$ & $0.95 \mathrm{a}$ \\
\hline Kompos jerami & $478.65 a$ & $478650 \mathrm{a}$ & $0.93 \mathrm{a}$ \\
\hline Tanpa organik & $462.78 \mathrm{a}$ & $462780 \mathrm{a}$ & $0.91 \mathrm{a}$ \\
\hline Interaksi & $*$ & $*$ & tn \\
\hline
\end{tabular}

Keterangan: Angka yang diikuti huruf yang sama pada kolom yang sama tidak berbeda nyata berdasarkan DMRT taraf $\alpha=5 \%$. menunjukkan interaksi antara pupuk anorganik dan organik. tn menunjukkan interaksi yang tidak nyata antara pupuk anorganik dan organik

yang sempit ini dilakukan oleh tanaman sebagai upaya mengurangi proses transpirasi. Berbeda pada perlakuan pupuk organik. Pupuk organik tidak berpengaruh nyata pada nilai total evapotranspirasi dan efisiensi air. Namun menurut Intara et.al (2011) penambahan pupuk kandang dan kompos dapat meningkatkan kadar air tanah dan kapasitas air tersedia.

\section{KESIMPULAN}

Perlakuan tanpa $\mathrm{P}$, tanpa $\mathrm{K}$ dan NPK meningkatkan pertumbuhan jumlah anakan sebesar $44-49 \%$, nilai SPAD $11-12 \%$, produksi $23-51 \%$ dibandingkan perlakuan tanpa pupuk NPK dan tanpa N. Efisiensi pemakaian air tertinggi yaitu $1.17 \mathrm{~g} \mathrm{gabah} \mathrm{L}^{-1}$ pada perlakuan tanpa P. Pupuk organik tidak meningkatkan pertumbuhan, produksi dan efisiensi penggunaan air. Interaksi pupuk anorganik dan organik mempengaruhi jumlah anakan, jumlah malai per rumpun, berat 1,000 butir dan total evapotranspirasi. Penambahan pupuk kandang sapi sangat mempengaruhi jumlah anakan dan total evapotranspirasi pada perlakuan tanpa pupuk P.

\section{DAFTAR PUSTAKA}

Arif, C., B.I. Setiawan, H.A. Sofiyuddin, L.M. Martief, M. Mizoguchi, R. Doi. 2012. Estimating crop coefficient in intermittent irrigation paddy fields using excel solver. Rice Sci. 19:143.

[Balittanah] Balai Penelitian Tanah. 2009. Petunjuk Teknis Edisi 2: Analisis Kimia Tanah, Tanaman. Air dan Pupuk. Balai Penelitian Tanah, Bogor.
BPS. 2021. Hasil sensus penduduk 2020. https://www.bps. go.id [2 November 2021].

Cui, X., Y. Zhang, J. Gao, F. Peng, P. Gao. 2018. Longterm combined application of manure and chemical fertilizer sustained higher nutrient status and rhizospheric bacterial diversity in reddish paddy soil of Central South China. Sci. Rep. 8:1-11.

Esfahani, M., H.R.A. Abbasi, B. Rabiei, M. Kavousi. 2008. Improvement of nitrogen management in rice paddy fields using chlorophyll meter (SPAD). Paddy Water Environ. 6:181-188.

Herdiyanti, H., E. Sulistyono, Purwono. 2021. Pertumbuhan dan produksi beberapa varietas padi (Oryza sativa L.) pada berbagai interval irigasi. J. Agron. Indonesia 49:129-135.

Hidayah, F., S. Santosa, R.E. Putri. 2019. Model prediksi hasil panen berdasarkan pengukuran non-destruktif nilai klorofil tanaman padi. Agritech. 39:289-297.

Hikmah, Z.M., N. Agustiani, S. Sriyana, K. Hayashi. 2017. Karakterisasi keragaan agronomis varietas padi sawah tadah hujan pada pemupukan nitrogen dan perlakuan air. J. Lahan Suboptimal 6:176-184.

Horta, C., M. Roboredo, J.P. Carneiro, A.C. Duarte, J. Torrent. 2018. Organic amendments as a source of phosphorus: agronomic and environmental impact of different animal manures applied to an acid soil. Arch. Agron. Soil Sci. 64:257-271. 
Hou, M., F. Lou, D. Wu, X. Zhang, M. Lou, D. Shen, M. Yan, C. Mao, X. Fan, G. Xu, Y. Zhang. 2021. OsPIN9 an auxin efflux carrier is required for the regulation of rice tiller bud outgrowth by ammonium. New Phytol. 229:935-949.

Intara, Y.I., A. Sapei, Erizal, N. Sembiring, MHB. Djoefrie. 2011. Pengaruh pemberian bahan organik pada tanah liat dan lempung berliat terhadap kemampuan mengikat air. J. Ilmu Pert. Ind. 16:130-135.

Jing, Y., Y. Zhang, I. Han, P. Wang, Q. Mei, Y. Huang. 2020. Effects of different straw biochars on soil organic carbon, nitrogen, available phosphorus, and enzyme activity in paddy soil. Sci. Rep. 10:1-12.

Leghari, S.J., N.A. Wahocho, G.M. Laghari, A.H. Laghari, G.M. Bhabhan, K.H. Talpur, T.A. Bhutto, A.A. Lashari. 2016. Role of nitrogen for plant growth and development: A Review. Adv. Environ. Biol. 10:209218.

Legowo, D.Y.H., F. Nurrochmad, E.P. A. Pratiwi. 2020. Analysis of water-saving irrigatuion with organic material at different percentages for rice cultivation. J. Civil. Eng. Forum 6:157-170.

Lestari, T., Trikoesoemaningtyas, S.W. Ardie, D. Sopandie. 2017. Peranan dalam meningkatkan toleransi tanaman sorgum terhadap cekaman alumunium. J. Agron. Ind. 45:43-48.

Li, T., J. Gao, L. Bai, Y. Wang, J. Huang, M. Kumar. 2019. Influence of green manure and rice straw management on soil organic carbon, enzyme activities and rice yield in red paddy soil. Soil Till. Res. 195:1-7.

Mashtura, S.P., Sufardi, Syakur. 2013. Pengaruh pemupukan phosfat dan sulfur terhadap pertumbuhan dan serapan hara serta efisiensi hasil padi sawah (Oryza sativa L.). J. Manaj. Sumberdaya Lahan. 2:285-295.

Pacheco, F.A.L., L.F.S. Fernandes, R.F.V. Junior, C.A. Valera, T.C.T. Pisarra. 2018. Land degradation: Multiple environmental consequences and routes to neutrality. Curr. Opin. Environ. Sci. Health. 5:79-86.

Pusat Data dan Sistem Informasi Pertanian. 2019. Buletin konsumsi pangan. Kementerian Pertanian.
Siska, W., I. Lenin. 2020. Pemupukan NPK dan nitrogen pada tanaman padi di lahan sawah berstatus $P$ tinggi di Sumatera Barat. J. Pengkaj. dan Pengemb. Teknol. Pertan. 22:175.

Siwanto, T., Sugiyanta, M. Melati. 2015. Peran pupuk organik dalam peningkatan efisiensi pupuk anorganik pada padi sawah (Oryza sativa L.). J. Agron. Indonesia 43:8-14.

Soebandiono, S., A. Muhibuddin, E. Purwanto,-D. Purnomo. 2021. Effect of indigenous organic fertilizer on the growth and yield of paddy. IOP Conf. Ser. : Earth Environ. Sci. 653:1-7.

Sosrodarsono, S., K. Takeda. 1983. Hidrologi untuk Pengairan. PT. Pradnya Paramita.

Sulistyono, E., Suwarno, I. Lubis. 2011. Karakterisasi morfologi dan fisiologi untuk mendapatkan marka morfologi dan fisiologi padi sawah tahan kekeringan $(-30 \mathrm{kPa})$ dan produktivitas tinggi $\left(>8\right.$ ton $\left.\mathrm{ha}^{-1}\right)$. Agrovigor 6:92-102.

Suyono, AD., A. Citraresmini. 2010. Komposisi kandungan fosfor pada tanaman padi sawah (Oryza sativa L.) berasal dari pupuk $\mathrm{P}$ dan bahan organik. Bionatura-J. Ilmu Hayati Fisik. 12:126-135.

Tang, H., C. Li, X. Xiao, L. Shi, K. Cheng, L. Wen, W. Li. 2020. Effect of short-term manure nitrogen input on soil microbial community structure and diversity in a double-cropping paddy field of southern China. Sci. Report. 10:13540.

Triadiati, A.A. Pratama, S. Abdulrachman. 2012. Pertumbuhan dan efisiensi penggunaan nitrogen pada padi (Oryza sativa L.) dengan pemberian pupuk urea yang berbeda. Bul. Anatomi Fisiol. 20:1-14.

Wang, S.X., X.Q. Liang, Q.X. Luo, F. Fan, Y.X. Chen, Z.Z. Li, H.X. Sun, T.F Dai, J.N. Wan, X.J. Li. 2012. Fertilization increases paddy soil organic carbon density. J. Zhejiang Univ. Sci. B 13:274-282.

Widianti, P., Violita, C. Chatri. 2017. Luas indeks stomata daun tanaman padi (Oryza sativa L.) varietas Cisokan dan Batang Piaman akibat cekaman kekeringan. Bioscience. 1:77-86. 
Xiao, M., H. Zang, T. Ge, A. Chen, Z. Zhu. P. Zhou, C.T. Atere, J. Wu, Y. Su, Y. Kuzyakov. 2019. Effect of nitrogen fertilizer on rice photosynthate allocation and carbon input in paddy soil. Eur. J. Soil Sci. 70: 786-795.

Xiong, Q., G. Tang, L. Zhong, H. He, X. Chen. 2018. Response to nitrogen deficiency and compensation on physiological characteristics, yield formation, and nitrogen utilization of rice. Front. Plant Sci. 9:1-14.

Yang, S., X. Chen, Z. Jiang, J. Ding, X. Sun, J. Xu. 2020. Effect of biochart application on soil organic carbon composition and enzyme activity in paddy soil under water saving irrigation. Int. J. Environ. Res. Public Health 17:2-17.

Yin, X., J. Chen, F. Cao, Z. Tao, M. Huang. 2020. Shortterm application of biochar improves post-heading crop growth but reduces pre-heading biomass translocation in rice. Plant Prod. Sci.:1-7.

Yuan, Z., Q. Cao, K. Zhang, S.T. Karim, Y. Tan, Y. Zhu, W. Cao, X. Liu. 2016. Optimal leaf positions for SPAD meter measurement in rice. Front. Plant Sci. 7:1-10. 